\title{
KNOWLEDGE, ATTITUDE AND SEVERITY OF MENOPAUSAL SYMPTOMS AMONG WOMEN ATTENDING PRIMARY HEALTH CARE CENTERS IN CAIRO, EGYPT
}

\author{
By \\ Alaa Abdelwahed Shams-Eldin \\ Department of Community Medicine and Industrial Medicine, Faculty of Medicine, \\ Al-Azhar University
}

\begin{abstract}
Background: Menopause is a physiologic process. Understanding its nature and symptoms can help women to adapt good quality of life during this period. There are shortages of recent data about this issue in Egyptian literature.

Objectives: This study aimed to assess knowledge and attitude towards menopause among women aged 4060 years attending primary health care centers (PHCs) in Cairo, Egypt, and to assess the severity of menopausal symptoms among them.

Subjects and Methods: A cross-sectional study was conducted in Cairo, Egypt. The sample size included data from 300 Egyptian women. A multistage cluster sampling technique was used to randomly select the studied two centers; El-Hagana family medicine center, and 6th district family medicine center at Nasr city. The data were collected from the studied women aged 40-60 years attending these centers by a valid structured questionnaire. The questionnaire included socio-demographic and reproductive data, and the Menopause Rating Scale rate scale (MRS) to assess the severity of menopausal symptoms. The collected data were analyzed using the appropriate statistical methods.

Results: The mean age at menopause of the studied women was $46.6 \pm 3.4$ years. The level of good knowledge about menopause was significantly low among perimenopausal and postmenopausal women. Positive attitude towards menopause, however, was prevalent regarding most studied attitude items. The mean severity score of somatic symptoms was significantly high among perimenopausal and postmenopausal women. Also, the mean psychological and urogenital symptoms severity scoring was significantly high among these women. The mean total severity score was significantly high in perimenopausal women.
\end{abstract}

Conclusion: The mean age at menopause was low. The observed low level of good knowledge necessitates more efforts for creating mass awareness about this issue.

Key words: Attitude, Knowledge, Menopause, Cross sectional study.

\section{INTRODUCTION}

Menopause is physiological event and marks the end of the natural reproductive capacity of a woman, defined as the permanent cessation of menstrual periods, determined retrospectively after a woman has experienced 12 months of amenorrhea without any other obvious physiological cause or pathological cause (Ande eta al., 2011). It is a reflection of complete, or near complete, ovarian follicular 


\section{ALAA ABDELWAHED SHAMS-ELDIN}

depletion, with resulting hypoestrogenemia and high folliclestimulating hormone concentrations (Lund, 2008 and Ande et al., 2011).

The menopausal transition, or perimenopause, begins on average four years before the final menstrual period, and is characterized by irregular menstrual cycle and marked hormonal fluctuations (Lund, 2008), while the premenopause is used either to refer to the one or two years immediately before the menopause or to refer to the whole of the reproductive period prior to menopause (Han and Lee, 2013).

Age of onset of natural menopause also varies worldwide. In the US, the median age at menopause is 51 years (Fleming et al., 2008), while across Europe; age of onset of natural menopause is higher with a mean of 50.7 years and a median of 54.3 years (Dravta et al., 2009). Data from Arabic countries showed that showed a mean age \pm SD of $48.4 \pm 3.8$ years in the $\mathrm{UAE}$, and $48.7 \pm 2.9$ years in Bahrain (Jassim and Al-Shaboul, 2008). In Egypt, however, the mean age at menopause is lower compared to data from Arabic countries (Hammam et al., 2012). The most prevalent postmenopausal symptoms among Egyptian women were joint pain, followed by sleep problems and physical and mental exhaustion (Sweed et al., 2012).

Hormonal changes at the menopause are associated with multiple physical and psychological symptoms like vasomotor symptoms, vaginal dryness, sleep disturbance, mood changes, depression, urinary incontinence, cognitive changes, and increased health risks for several chronic disorders including osteoporosis, and cardiovascular disease (Lim, 2013). The duration, severity and impact of these symptoms vary tremendously from woman to woman and population to population, but menopausal symptoms can profoundly affect women's quality of life. Knowing more about menopause can help women to adapt better with menopausal change, and several studies have reported that women may avoid and reduce many adverse psychological symptoms of menopause by educating themselves about menopause (Kwak et al., 2014).

Whether or not the psychological and emotional problems reported by some menopausal women can be attributed specifically to the menopausal transition is a controversial issue. Symptoms experienced by women during and after the menopausal transition are influenced by preconceived knowledge and attitudes toward the menopause, personality type, and exposure to a greater or lesser degree of life stressors (Kwak et al., 2014).

According to available literature, there is limited data about the knowledge and attitude towards menopause and the severity of its associated symptoms among women in Egypt (Sweed et al., 2012).

This study aimed to assess knowledge and attitude towards menopause among Egyptian women attending PHCs in Cairo, and to assess the severity of menopausal symptoms among them.

\section{SUBJECTS AND METHODS}

The present cross sectional study was carried out among Egyptian women attending two primary health care centers in Cairo during the period from the $1^{\text {st }}$ of September 2017 to the end of January 
2018, to measure their knowledge and perception towards menopause and to assess the severity of menopausal symptoms among them. The target population of this study was all women aged from 40-60 years attending PHCs during the study period. The sample size was calculated according to a confidence interval of $95 \%$, a marginal error of $5 \%$, and a proportion of knowledge among women of the same age in a previous study. Finally, the calculated sample size was 300 women.

For selection of study population, the multistage cluster sampling technique was employed as follow: the first stage included the random selection of one health affairs directorate in Cairo (health affairs directorate for Eastern Cairo). The 2nd stage included random selection of two PHCs from the chosen directorate. The randomly selected PHCs were: ElHagana family medicine center and 6th district family medicine center at Nasr city. Each studied center was visited twice weekly during the study period.

The data were obtained from the studied subjects through a structured anonymous questionnaire. The questionnaire included questions about personal data such as age, marital status, educational level and monthly family income. Reproductive characteristics included age of menarche, number of pregnancies and abortion and regularity of the menstrual cycle, and data concerning knowledge and attitude towards menopause. The last section of the questionnaire was used to measure the severity of menopausal symptoms among the studied women. The data were collected from the target women by face to face interviewing in the selected PHCs after obtaining the consent and giving a brief explanation of the objective of the study.

The knowledge about menopause was based on 24 questions. Each of these questions has two answers (yes and no). The knowledge was assessed and categorized into good, fair and poor according to knowledge score given for each of its component. Good knowledge was defined if the subjects' answer by "yes" was more than $75 \%$, fair knowledge if between (50-75\%), and finally poor knowledge if less than $50 \%$ (Kwak et al., 2014). Attitudes towards menopause was assessed using Likert response scale from $1-5(1=$ totally disagree; $2=$ disagree $3=$ neutral; $4=$ agree; $5=$ totally agree). The percentage of women with favorable attitude (totally agree and agree) was calculated among the studied women and compared by their menopausal status. The knowledge and attitude variables used in the questionnaire were adapted from similar previous studies (Sweed et al., 2012; Noroozi et al., 2013 and Kwak et al., 2014). These data were validated through revision by Obs/Gyna and family medicine consultants.

The severity of menopausal symptoms was assessed by using Menopause Rating Scale (MRS) questionnaire. MRS has been validated and widely used in many clinical and epidemiological studies, and in research on the etiology of menopausal symptoms to assess the severity of menopausal symptoms (Cohen et al., 2006). As there is no Arabic version of this scale, the English version was translated into Arabic language. The translation was verified by back- 


\section{ALAA ABDELWAHED SHAMS-ELDIN}

translation performed by a different bilingual person.

The MRS is composed of 11 items and was divided into three subscales:

(i) somatic-hot flushes, heart discomfort/palpitation, sleeping problems and muscle and joint problems.

(ii) psychological-depressive mood, irritability, anxiety and physical and mental exhaustion.

(iii) Urogenital-sexual problems, bladder problems and dryness of the vagina.

Each of the eleven symptoms contained a scoring scale from "0" (no complaints) to "4" (very severe symptoms). The women were asked whether or not they had experienced the 11 menopausal symptoms shown in the MRS in the previous one month (30 days).

The menopausal status of women in this study was classified according to STRAW (Stages of Reproductive Aging Workshop) classification which divided menopause staging into: Postmenopausal; no menstrual bleeding in the previous/last 12 months. perimenopause; had increasing irregularity of menses without skipping periods (Soules et al., 2001) and Premenopause; refer to the whole of the reproductive period prior to menopause (Shore, 1999).
The data were analyzed using the statistical analysis system (SAS) software package (SAS, 1999). The data were tabulated and presented in frequency number and percent. Chi square and Fischer exact test were used as appropriate to compare the studied categorical variables (level of knowledge (good, fair and poor), and the percentage of favorable (positive attitude)) by menopausal status of the studied women (premenopause, perimenopause, and menopause). Comparison of menopausal symptoms scores (total, somatic, psychological and urogenital was compared among the studied women by using one way ANOVA post-hoc test analysis. The level of $\mathrm{P}<0.05$ was considered as the cut-off value for significance.

The approval for this study was obtained by the Ethics Committee at the faculty of medicine, Al-Azhar University, Cairo, Egypt. Approval was also taken from the directorates of the studied centers before starting the field work of the study. The participation was voluntary and anonymous. All women gave their informed consent prior to their inclusion in the study. Confidentiality and privacy of the collected data were assured, and the data were only used for the research purpose.

\section{RESULTS}

The study analyzed data from 300 Egyptian women aged from 40 to 60 years. Table 1 presented the personal characteristics of the studied subjects. The mean age of the studied women was 47.7 \pm 3.1 years and most of them $(89 \%)$ were above the age of 45 years. The majority of the studied women were university and higher educational level (95\%), and more than two thirds \% of them was married $(68.3 \%)$. The monthly family income was exceeding 5000 LE represented only 3\% of the studied women. 
Table (1): Personal characteristics of the studied women

\begin{tabular}{|l|c|}
\hline \multicolumn{1}{|c|}{ Characteristics** } & N= 300 \\
\hline Age (years) & \\
$\leq 45$ & $33(11.0)$ \\
$>45$ & $267(89.0)$ \\
Mean \pm SD (Range) & $47.7 \pm 3.1(40-60)$ \\
\hline Marital status & $205(68.3)$ \\
Married & $95(31.7)$ \\
Not married** & \\
\hline Educational level & $15(5.0)$ \\
Less than university & $285(95.0)$ \\
University and higher & $279(93.0)$ \\
\hline Family income/month & $12(4.0)$ \\
$<3000$ LE & $9(3.0)$ \\
$3000-5000$ LE & \\
$\geq 5000$ LE & \\
\hline
\end{tabular}

*Data were presented by mean \pm SD or by n. $(\%)$

** Not married category included 3 single, 23 divorced and 69 widow women

Table (2) presented the reproductive characteristics of the studied women. Their mean age of menarche was $13.4 \pm$ 1.6 years. The mean number of pregnancies of the studied women was 4.7 \pm 2.2 , the mean number of abortions was $0.84 \pm 1.3$, and the mean number of living children was $3.6 \pm 1.4$. More than half of the studied women $(51.3 \%)$ reported menopause, $29.7 \%$ showed irregularity of menstruation (Perimenopausal), and 19\% reported regularity of their cycles (Premenopausal). The mean perimenopausal and menopausal age of the studied women was $45.7 \pm 2.5$ and $46.6 \pm 3.4$, respectively.

Table (2): Reproductive characteristics of the studied women

\begin{tabular}{|l|c|}
\hline Characteristics $^{*}$ & $\mathbf{N}=\mathbf{3 0 0}$ \\
\hline Age of menarche in years; mean \pm SD (Range) & $13.4 \pm 1.6(11-18)$ \\
\hline Number of pregnancies; mean \pm SD (Range) & $4.7 \pm 2.2(0-8)$ \\
\hline No of abortions; mean \pm SD (Range) & $0.84 \pm 1.3(0-7)$ \\
\hline Number of living children; mean \pm SD (Range) & $3.6 \pm 1.4(0-8)$ \\
\hline Regularity of menstruation: n (\%) & $57(19.0)$ \\
Regular & $89(29.7)$ \\
Irregular (Perimenopausal) & $154(51.3)$ \\
Menopause & $45.7 \pm 2.5(42-50)$ \\
\hline Perimenopausal age; mean \pm SD (Range) & $46.6 \pm 3.4(38-52)$ \\
\hline Menopausal age; mean \pm SD (Range) & \\
\hline
\end{tabular}

$*$ Data were presented by the mean \pm SD or by $n(\%)$.

Table (3) presented the level of knowledge of the studied women about menopause by their menopausal status.
The percentage of good level of knowledge was higher among postmenopausal women (15.5\%) 
compared to $3.4 \%$ among perimenopausal women and $0 \%$ among premenopausal women. The percentage of the studied women with fair level of knowledge was high in all studied groups. The level of poor knowledge, however, was the highest among premenopausal women (36.9\%), and postmenopausal women $(30.6 \%)$. The analysis showed statistically significant differences $(p=0.003)$.

Table (3): Level of knowledge of the studied women about symptoms of menopause versus to menopausal status

\begin{tabular}{|c|c|c|c|c|}
\hline \multirow{2}{*}{ Menopausal status } & $\begin{array}{c}\text { Pre- } \\
\text { menopausal } \\
(\mathbf{n = 5 7 )}\end{array}$ & $\begin{array}{c}\text { Peri- } \\
\text { menopausal } \\
(\mathbf{n = 8 9})\end{array}$ & $\begin{array}{c}\text { Post- } \\
\text { menopausal } \\
(\mathbf{n = 1 5 4})\end{array}$ & $\begin{array}{c}\text { P } \\
\text { value }\end{array}$ \\
\cline { 1 - 4 } & $0(0.0)$ & $3(3.4)$ & $24(15.5)$ & \\
\cline { 1 - 4 } Good & $36(63.1)$ & $65(73.0)$ & $83(53.9)$ & \multirow{2}{*}{0.003} \\
\hline Fair & $21(36.9 \%)$ & $21(23.6)$ & $47(30.6)$ & \\
\cline { 1 - 3 }
\end{tabular}

Table (4) displayed the comparison of favorable attitude of the studied women towards menopause by their menopausal status. There have been statistically significant differences among the studied women regarding the favorable (positive attitude) of the following attitude items: "Menopause is the end period for menstrual problems and contraception",

Table (4): Comparison of women with favorable attitude items by their menopausal status

\begin{tabular}{|l|c|c|c|c|}
\hline Mavorable attitude & $\begin{array}{c}\text { Mre- } \\
\text { menopausal } \\
(\mathbf{n = 5 7 )}\end{array}$ & $\begin{array}{c}\text { Peri- } \\
\text { menopausal } \\
\text { (n=89) }\end{array}$ & $\begin{array}{c}\text { Post- } \\
\text { menopausal } \\
\text { (n=154) }\end{array}$ & $\begin{array}{c}\text { P } \\
\text { value }\end{array}$ \\
\hline $\begin{array}{l}\text { Menopause is the end period for } \\
\text { menstrual problems and } \\
\text { contraception }\end{array}$ & $45(80.0)$ & $86(96.6)$ & $142(92.2)$ & 0.01 \\
\hline $\begin{array}{l}\text { Every woman can train herself to } \\
\text { cope with the period of menopause }\end{array}$ & $51(89.5)$ & $86(96.6)$ & $148(96.1)$ & 0.10 \\
\hline $\begin{array}{l}\text { Menstrual interruption, reduces the } \\
\text { attention of women to her husband }\end{array}$ & $33(27.5)$ & $13(22.8)$ & $2(6.9)$ & $<.0001$ \\
\hline $\begin{array}{l}\text { Compared to pre-menopause, } \\
\text { menopause and women's life will } \\
\text { be more enjoyable after a break }\end{array}$ & $9(16.0)$ & $6(7.0)$ & $60(39.0)$ & 0.18 \\
\hline $\begin{array}{l}\text { Menstrual impairment reduces the } \\
\text { beauty and attractiveness of } \\
\text { women }\end{array}$ & $30(52.6)$ & $44(49.4)$ & $94(61.0)$ & 0.69 \\
\hline $\begin{array}{l}\text { Menopause is the beginning of a } \\
\text { new life and other maturation for } \\
\text { women }\end{array}$ & $45(79.0)$ & $68(76.4)$ & $112(72.7)$ & 0.60 \\
\hline $\begin{array}{l}\text { Women's social activity is reduced } \\
\text { after menopause }\end{array}$ & $12(21.1)$ & $15(16.9)$ & $57(37.0)$ & 0.32 \\
\hline
\end{tabular}


Table (5) showede the mean scoring of menopausal symptoms of the studied women by their menopausal status. The mean score of severity of somatic symptoms was significantly high among perimenopausal $(7.4 \pm 2.6)$ and postmenopausal $(7.1 \pm 2.5)$. Psychological symptoms severity was also higher among perimenopausal and postmenopausal compared with premenopausal women, with statistically significant difference ( $p$ $<0001$ ). Urogenital symptoms showed significant high severity among perimenopausal and postmenopausal with the mean scoring among these women was $4.1 \pm 2.6$ and $3.4 \pm 2.8$, respectively. The mean total menopausal severity scoring was also significantly highest among perimenopausal (21.7 \pm 5.6) and postmenopausal $(18.4 \pm 7.1)$ women.

Table (5): Mean scoring of menopausal symptoms of the studied women by their menopausal status

\begin{tabular}{|c|c|c|c|c|}
\hline $\begin{array}{r}\text { Menopausal } \\
\text { status }\end{array}$ & $\begin{array}{c}\text { Pre- } \\
\text { menopausal } \\
(n=57)\end{array}$ & $\begin{array}{c}\text { Peri- } \\
\text { menopausal } \\
(n=89)\end{array}$ & $\begin{array}{c}\text { Post- } \\
\text { menopausal } \\
(n=154)\end{array}$ & $\begin{array}{c}\mathrm{P}- \\
\text { value }\end{array}$ \\
\hline Menopausal symptoms & & & & \\
\hline Somatic scores & $5.7 \pm 3.8$ & $7.4 \pm 2.6$ & $7.1 \pm 2.5$ & 0.001 \\
\hline Psychological scores & $7.3 \pm 4.2$ & $10.2 \pm 3.3$ & $7.9 \pm 3.7$ & $<.0001$ \\
\hline Urogenital scores & $2.9 \pm 2.7$ & $4.1 \pm 2.6$ & $3.4 \pm 2.8$ & 0.03 \\
\hline Mean total scoring & $16.1 \pm 8.7$ & $21.7 \pm 5.6$ & $18.4 \pm 7.1$ & $<.0001$ \\
\hline
\end{tabular}

\section{DISCUSSION}

The present cross sectional study analyzed data from 300 Egyptian women attending PHCs in Cairo, to assess their knowledge and attitude towards menopause and to estimate the severity of menopausal symptoms among them. The mean age at menopause among the studied women was $46.6 \pm 3.4$ years. Comparable with this finding, a previous Egyptian study has reported similar mean age at menopause (Hammam et al., 2012). However, the age at menopause in that and the present study was low compared with the mean age reported in Western and Arabic studies. In Europe, the age of onset of natural menopause is higher with a mean of 50.7 years and a median of 54.3 years (Dravta et al., 2009). Data from Arabic countries showed a mean age \pm SD of $48.4 \pm 3.8$ years in the UAE, $48.7 \pm 2.9$ years in Bahrain (Al-Shaboul, 2008). The difference in the mean age of menopause in these studies might be attributed to the difference in their design, sampling size and the study setting where women were included.

The results of the study indicated a low level of good knowledge of the studied women, particularly among premenopausal and perimenopausal. These findings were consistent with the results of most similar studies conducted regionally (Lim, 2013 and Kwak et al., 2014). Also, the results of studies conducted in developing countries were comparable with the results of this study to some extent (Taherpour et al., 2015). On the other hand, the results of studies are different in developed countries. In Korea, the knowledge level of most of the studied women about menopause was 
reported as good (Park and Lee, 2011). However, in Italy, the report of similar study indicated that more than half of the samples had no information about menopause (Donati et al., 2009). The low level of knowledge among the studied women in this and other similar regional studies may be attributed to the neglected postmenopausal issue by the medical and mass media community in our region.

Table 4 revealed a prevalent positive findings and agreement with most of the studied attitude items about menopause. The prevalence of agreement was high and approaching more than $90 \%$ for some of the studied attitude items. These results agreed with previous similar study results (Donati et al., 2009; Kwak et al., 2014 and Taherpour et al., 2015). (Donati et al., 2009) have reported that over $90 \%$ of the samples knew menopause as a positive event and had a positive attitude toward it.

In our study, although the level of knowledge was inadequate, the majority of the studied women have had positive attitude towards menopause. The higher educated percent of women in this study affect the way of their thinking and attitude about menopause as it is just stage and not the end of their life (Noroozi et al., 2013).

The study findings revealed a significant high mean scoring of menopausal symptoms of the studied women by their menopausal status. The mean score of severity of somatic symptoms was significantly high among perimenopausal and postmenopausal. These findings agree with studies carried out in Pakistan (Nusrat et al., 2008) and India (Dutta et al., 2012) showed a high prevalence of hot flushes in the studied women of $59.4 \%$ and $60.9 \%$, respectively, although not stratified by the menopausal status of the studied women.

Psychological symptoms severity was also higher among perimenopausal and postmenopausal in the present study. Similar studies were also reported high prevalence of psychological and sleep disturbance among the postmenopausal women reaching up to $70 \%$ in some studies (Dasgupta and Ray, 2009). A much higher proportion, however, was reported in other similar Asian studies (Kaulagekar, 2011 and AlQuaiz et al., 2013). Urogenital and sexual symptoms were also prevalent among the perimenopausal and postmenopausal women in this study with a significant high mean scoring among perimenopausal and postmenopausal of $4.1 \pm 2.6$ and $3.4 \pm$ 2.8 , respectively.

\section{CONCLUSION}

The mean age at menopause among the studied women were low compared with that in similar regional and international studies. Although most of the studied women were highly educated, the study results revealed low level of good knowledge about menopause among them. This finding necessitates the need to introduce knowledge about menopause in higher educational curriculum, and to do more efforts for creating mass awareness about this issue. As menopausal symptoms scoring was high among the studied women during their menopausal and menopausal transition, future studies have to address the methods used in the management of menopausal associated symptoms. Such studies have to include large cohort of women from different regions and belonging to different socio- 
cultural and educational levels. Finally, designing and implementing a proper health education program and disseminating it on a large scale through different mass media can have an effective and valuable role in improving women's knowledge about menopause in the country.

\section{REFERENCES}

1. AlQuaiz AM, Tayel SA and Habiba FA. (2013): Assessment of symptoms of menopause and their severity among Saudi women in Riyadh. Ann Saudi Med., 33(1): 63-67.

2. Ande AB, Omu OP, Ande O, and Olagbuji NB. (2011): Features and perceptions of menopausal women in Benin City, Nigeria. Annals of African Medicine, 10(4): 300-304.

3. Cohen L, Soares C and Vitonis A. (2006): Risk for new onset of depression during the menopausal transition: the Harvard study of moods and cycles. Arch Gen Psychiatry, 63: 386-390.

4. Dasgupta D and Ray S. (2009): Menopausal problems among rural and urban. Women from Eastern India. J Soc Health Sci., 20-33.

5. Donati S, Cotichini R, Mosconi P, Satolli R, Colombo $C$ and Liberati A. (2009): Menopause: Knowledge, attitude and practice among Italian women. Maturitas, 63: 246-252.

6. Dravta J, Real F and Schindler C. (2009): Is age at menopause increasing across Europe? Results on age at menopause and determinants from two population-based studies. Menopause, 16(2): 385-394.

7. Dutta R, Dcruze L, Anuradha R, Rao S and Rashmi MR. (2012): Population based study on the menopausal symptoms in a rural area of Tamil Nadu, India. J Clin Diagn Res., 6: $597-$ 601.

8. Fleming L, Levis $S$ and LebBlanc W. (2008): Earlier age at menopause, work and tobacco smoke exposure. Menopause, 15(6): 11031108 .

9. Hammam $\mathbf{R}$, Abbas $\mathbf{R}$ and Hunter MS. (2012): Menopause and work - The experience of middle-aged female teaching staff in an Egyptian governmental faculty of medicine. Maturitas, 71(3): 294-300.

10. Han MJ and Lee JH. (2103): Factors influencing self-identity and menopausal symptoms on level of depression in middle aged women. Korean J Women Health Nurs., 19: $275-284$.

11. Jassim G and Al-Shaboul Q. (2008): Attitude of Bahraini women towards the menopause: implication for health policy. Maturitas, 59: 358-372.

12. Kaulagekar A. (2011): Age of menopause and menopausal symptoms among urban women in Pune, Maharashtra. J Obstet Gynecol India, 61:323-326.

13. Kwak EK, Park HS and Kang NM. (2014): Menopause Knowledge, Attitude, Symptom and Management among Midlife Employed Women. Journal of Menopausal Medicine, 20(3): 118-125.

14. Lim KY. (2013): The study of menopauserelated quality of life and management of climacteric in a middle-aged female population in Korea. Public Health Wkly Rep., 6: 609-613.

15. Lund KJ. (2008): Menopause and the menopausal transition. Med Clin North Am., 92(5): 1253-12571.

16. Noroozi E, Dolatabadi NK, Eslami AA, Hassanzadeh A and Davari S. (2013): Knowledge and attitude toward menopause phenomenon among women aged 40-45 years. J Educ Health Promot., 2: 25-28.

17. Nusrat $\mathbf{N}$, Nishat $Z$, Gulfareen $H$, Aftab $M$ and Asia N. (2008): Knowledge, attitude and experience of menopause. J Ayub Med Coll Abbottabad., 20: 56-59.

18. Park JS and Lee YE. (2011): Effects of integrated menopause management program for middle aged woman. Korean J Women Health Nurs., 17: 10-20.

19. SAS Institute Inc (1999): Proprietary Software Release 8.2. Cary, NC, SAS Institute Inc, 1999.

20. Shore G. (1999): Soldiering on: An exploration intowomen's perceptions and 


\section{ALAA ABDELWAHED SHAMS-ELDIN}

experiences ofmenopause. Feminism and Psychology, 9: 168-180.

21. Soules MR, Sherman S and Parrot E. (2001): Executive summary: stages of reproductive aging workshop (STRAW). J Women's Health Gender-based, 10(9): 843-848.

22. Sweed HS, Elawam AE, Nabeel AM and Mortagy K. (2012): Postmenopausal symptoms among Egyptian geripausal women. East Mediterr Health J., 18(3): 213-20.

23. Taherpour M, Sefidi F, Afsharinia $S$ and Hamissi JH. (2015): Menopause knowledge and attitude among Iranian women. J Med Life, 8(2): 72-76. 


\section{معارف و اتجاهات و خطورة أعر اض سن اليأس بين السيدات المترددات على مر اكز الرعاية الصحية الأولية فى القاهرة علاء عبد الواحد شمس الدين}

قسم طب المجتمع و طب الصناعات ـ كلية الطب - جامعة الأزهر

خلفية البحث : سـن اليـأس عمليـة فسيولوجية و فهم طبيعتـه و أعر اضـه يمكن أن يسـاعد النسـاء على التكيف مع نو عية الحياة خلال هذه الفترة. هناك نقص في البيانات الحديثة حول هذه القضية فى مصر.

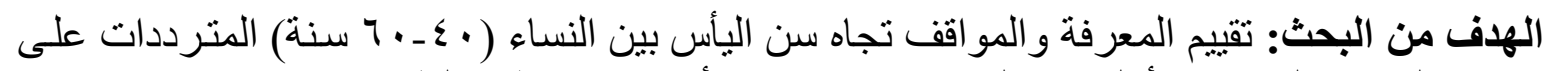
مر اكز الرعاية الصحية الأولية في القاهرة ، وتقييم شدة أعر اض إن إنقطاع الطمث بينهم.

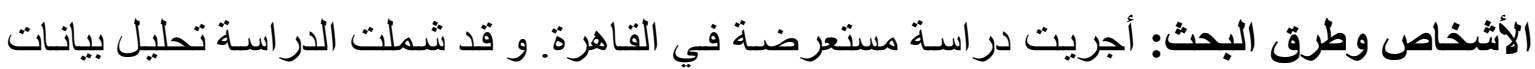

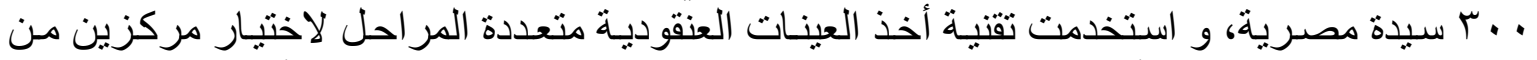

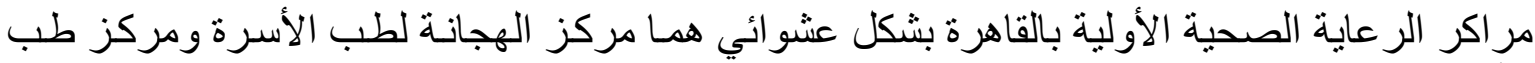

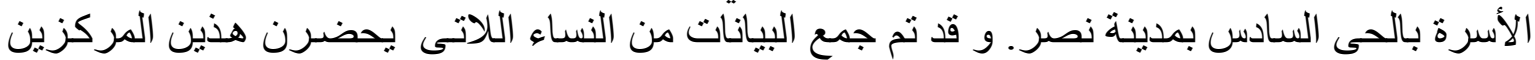

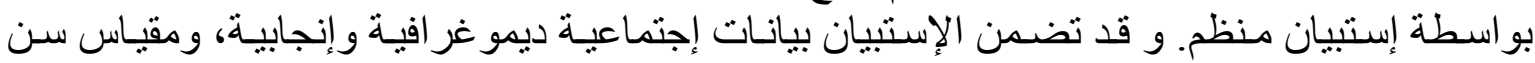
اليأس لتقييم شدة أعر اض إنشان منطاع الطمث.

و قد تم تحليل البيانات التي تم جمعها باستخدام الأساليب الإحصائية المناسبة.

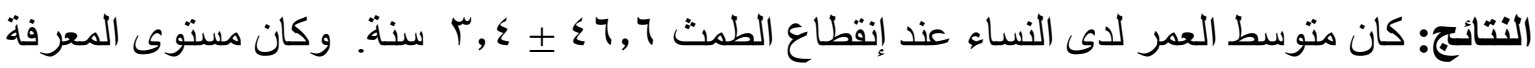
الجيدة حول إنقطاع الطمث منخفضًا بشكل ملحوظ بين النساء قبل إنقطاع الطمث و النساء اللاتي يعانين من إنقطاع الطمث. ومـع ذلك ، كان الموقف الإيجابي تجاه سـن اليأس سـائدا فيمـا بتعلق بمعظم بنود الدر اسة المدروسة. و كان متوسط معامل الخطورة للأعر اض الجسدية عالية بشكل ملحوظ لدى النسـاء اللاتـى إقتربن مـن سـن اليـأس و النسـاء بعد سـن اليـأس. و كـان متوسط معامـل الأعر اض النفسية و

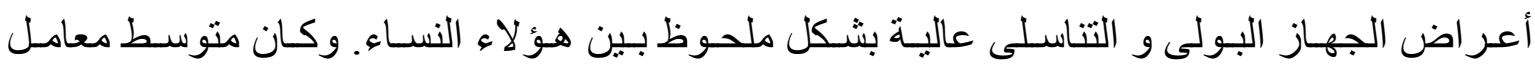
الخطورة الكلية مرتفعا بشكل ملحوظ في النساء قبل إنقطاع الطمث.

الاستتتاج: كان منوسط العمر عند سن اليأس منخفضًا لدى سيدات الدراسة. يتطلب المستوى المنخفض من المعرفة الجيدة لدى هؤلاء السيدات بذل المزيد من الجهود لخلق الوعي الجمـاهيري حول هذه 